\title{
THE CONTRADICTION AT THE HEART OF AMERICAN DEMOCRACY
}

\author{
Ethan J. Kytle
}

Robert Pierce Forbes. The Missouri Compromise and Its Aftermath: Slavery and the Meaning of America. Chapel Hill: University of North Carolina Press, 2007. 384 pp. Map, notes, and index. $\$ 45.00$.

In the first volume of Democracy in America, Alexis de Tocqueville wrote that the dilemmas of Native Americans and African Americans are "collaterally connected with my subject without forming a part of it; they are American without being democratic, and to portray democracy has been my principle aim. ${ }^{1}$ Preoccupied with determining the role democracy would play in Europe, Tocqueville felt little compunction to situate America's troubling pattern of race relations at the center of his study of democracy in the United States. Until recently, historians of the Early Republic have largely followed in Tocqueville's footsteps, at least in terms of the slavery question. But thanks to new works by Richard Newman, Adam Rothman, and Matthew Mason, among others, we now know far more about slavery in the Early Republic, ranging from the expansion of slavery into the Old Southwest to political debates about the future of the institution, from the development of the domestic slave trade to both radical and conservative approaches to abolition before the 1830s. ${ }^{2}$

Robert Pierce Forbes's new book, The Missouri Compromise and Its Aftermath, can be understood as the culmination of this historiographic campaign to reassess the role of slavery in the Early Republic. First, it exhaustively traces the debates about and significance of the era's most important piece of legislation relating to slavery: the Missouri Compromise. Second, it casts its gaze far beyond the Missouri Compromise proper, demonstrating the ways that politicians of the 1820s and early 1830s were consumed with questions about the future of slavery in the American republic. Ultimately, The Missouri Compromise and Its Aftermath makes a strong case that for much of the early history of the United States, slavery was "the contradiction at the heart of American democracy" (p. 49).

The first major study devoted to the Missouri Compromise in almost fifty years, Forbes's book does an admirable job summarizing the many responses it has provoked from historical actors and historians alike. In the wake of the 
Missouri Compromise, proslavery southerners celebrated the outcome, while opponents of the expansion of slavery lamented the results. By the 1850s, however, the tables were turned, inasmuch as southern firebrands viewed the Missouri Compromise as an abomination, while northern antislavery advocates believed it to be "a sacred pledge" (p. 278). And the disagreements were not simply sectional; rather, opinions often changed over time. In 1849, for example, Illinois senator Stephen Douglas insisted that the Missouri Compromise was "canonized in the hearts of the American people, as a sacred thing, which no ruthless hand would ever be reckless enough to disturb" (p. 274). Five years later, of course, it was Douglas's own hand that not only disturbed the Compromise, but, by engineering the passage of the Kansas-Nebraska Act, rendered it "inoperative and void" in those territories.

Historians have also sounded different notes about the Missouri Compromise. Whereas historians of the Early Republic have framed it "as a signal defeat for antislavery forces and a victory for the slave South," Civil War historians tend to "regard the Compromise as the cornerstone of antislavery nationalism and the chief bulwark against the growth of the 'peculiar institution'" (p. 3). Forbes's in-depth study, then, provides a useful roadmap to the vexing debates about, and legacy of, one of the most complicated and divisive political issues in American history.

In early 1819, James Tallmadge, a Republican congressman from New York, proposed an amendment to the Missouri statehood bill that launched two years of bitter debate on the issue of slavery. Tallmadge had deep reservations about slavery and hoped to put Missouri on the road to freedom by preventing "the further introduction of slavery" and mandating a program of gradual emancipation. Quickly, American congressmen began staking out sides in what Forbes describes as "the most candid discussion of slavery ever held in Congress" (p. 36). Tallmadge's ally, New York congressman John Taylor, turned simply to the words of slaveholders themselves. "How have they wept over the unfortunate policy that first introduced slaves into this country!" Taylor asserted. "How have they disclaimed the guilt and shame of that original sin, and thrown it back upon their ancestors!" (p. 37). Naturally, some proslavery supporters took umbrage at this approach, maintaining that Tallmadge's amendment was an egregious affront to property rights, which ultimately put the nation at risk. Still, they made careful arguments, wary of defending slavery too aggressively. Although some proslavery politicians pushed towards the "slavery as a positive good" position, most preferred indirect defenses of the institution, taking their stand on the constitutional grounds that Congress did not have the power to prohibit slavery in a state or territory.

Yet if antislavery congressmen seemed to hold the moral high ground, they did not represent a unified northern front. Despite the fact that northern states had a thirty-five-seat majority in the House of Representatives, the Tallmadge 
Amendment passed narrowly there. And the subsequent failure to restrict slavery from the Arkansas territory indicated that many northern congressmen were willing to seek out a middle ground on the question. But the Tallmadge Amendment's doom, at least in the Fifteenth Congress, was sealed in the Senate, which refused to pass the Missouri statehood bill with it.

When the Sixteenth Congress met from 1819 to 1821, the debate shifted from Congress to Washington's saloons, offices, and boarding houses. There, northerners and southerners, both obscure and esteemed, wrestled over the future of slavery in Missouri and the nation. President James Monroe, in Forbes's dense narrative, was a prime, but largely covert, player. The antislavery Monroe, it would seem, orchestrated a remarkable behind-the-scenes campaign for compromise. Largely through proxies, he sought to negotiate a settlement between proslavery southerners and antislavery northerners that would avert the civil war feared by many. For example, Henry Clay and John C. Calhoun, both of whom Forbes labels "lieutenants" of the president, sought to convince northern Secretary of State John Quincy Adams that disunion was the likely outcome of the Missouri controversy (p. 94). Forbes's portrayal of Monroe as a strong opponent of slavery, however, suffers from a lack of corroborating evidence. That he operated behind the scenes through his agents is plausible enough, but many of Forbes's claims go far beyond the realm of speculation. The proverbial "smoking gun" is nowhere to be found in his account.

Eventually, two compromises were necessary to solve the Missouri crisis. The first was forged in the foundry of sectional balance: Maine was admitted as a free state and Missouri as a slave state. In addition, Congress passed a bill outlawing slavery in the Louisiana Purchase Territory, north of the $36^{\circ}$ $30^{\prime}$ line, the southern boundary of the state of Missouri. Southerners were thrilled by the outcome. South Carolinian Charles Pinckney reported that "it is considered here by the slave-holding states as a great triumph." Northern restrictionists, in contrast, deemed themselves "conquered" (p. 98). The second compromise, largely a product of Henry Clay, was equally pleasing to proslavery forces. Clay formulated a sufficiently ambiguous compromise provision-Forbes aptly labels it "a landmark in deliberately obfuscatory legislative language" - so as to secure Missouri's admission despite a state constitution that permitted free blacks to be barred from entering the state (p. 118). Thus, southerners could view Missouri's anti-free black clause as entirely acceptable to Congress. Northerners were more equivocal about the second Missouri Compromise. Some breathed a sigh of relief that the crisis was over; others worried that Clay's "evasion" would lead inevitably to the conclusion that "a free black is not a citizen" (p. 119).

The latter response was prescient. For, as Forbes argues, the Missouri controversy had two critical legacies. One legacy was that the second compromise contained the seeds of destruction for the key antislavery measure- the $36^{\circ} 30^{\prime}$ 
prohibition line-in the first. By providing a precedent for depriving blacks of citizenship rights, Clay's ambiguously worded bill laid the foundation for the 1857 Dred Scott v. Sanford decision. That decision, in turn, ruled that the $36^{\circ} 30^{\prime}$ prohibition line was unconstitutional.

The second legacy of the Missouri Compromise was convincing many Americans that slavery posed the gravest of dangers to the republic. And, in the decade following the Missouri Compromise, most American politicians took this lesson to heart, studiously avoiding the divisive issue. Thinking the slavery question too explosive, if not completely settled, northerners and southerners found themselves drawn into intersectional coalitions that tend to shock later observers. The People's Party of New York, which was led by James Tallmadge, for example, backed proslavery leader John C. Calhoun, while Georgian William Crawford received the endorsement of abolitionist William Lloyd Garrison.

Underneath the surface, however, the slavery pot simmered without boiling over as emancipationists and anti-emancipationists battled to a draw. Whereas abolitionists failed to formulate a practical emancipation plan, slavery's supporters had difficulty locating a convincing argument in favor of the institution. But this battle was not without its casualties. Chief among them was the nationalist program embraced by Monroe and his successor, John Quincy Adams. Calling Adams's nationalist agenda "perhaps the most far-reaching scheme of national advancement ever proposed by an American president," Forbes lingers on the president's ambitious plan to use the federal government to transform the young republic through educational, scientific, and social programs (p. 191). Despite carefully avoiding the issue of slavery, Adams articulated a vision that resonated with the rising tide of the evangelical culture of beneficence, thereby scaring southern gentry. They feared what lay down that road. While Adams was silent on slavery, the fact that nine northern legislatures called for emancipation and colonization seemed to foretell the ultimate challenge to slavery posed by nationalist reform. Senator Rufus King even introduced a resolution whereby the federal government would fund colonization with the proceeds from the sale of public land. As King hoped, this proposal revived the public debate on slavery, leaving Georgia governor George Troup to predict that "the United States government, discarding the mask, will openly lend itself to a combination of fanatics for the destruction of every thing valuable in the country." His advice to southern planters was "to stand by your arms" (p. 196).

Troup's fears were unfounded, however, for the South had a better weapon: Martin Van Buren. The leading voice of the Jacksonian opposition since Adam's election, Van Buren had as little use for Adams as he had for his predecessor Monroe. Both presidents, after all, looked forward to a post-political party era in America. In contrast, Martin Van Buren viewed political parties as the 
sine qua non of American politics, if not life in general. But if the New Yorker often appeared to care for little beyond winning at the game of politics, he was not without clear commitments. Van Buren was unwavering in his opposition to Adams's ambitious plans because they were rooted in the "Monroe heresy" of party amalgamation. This, in turn, led him to seek out allies below the Mason-Dixon line. And so, "Van Buren quickly established himself as the most dependable, if not the most unguarded, northern defender of southern prerogatives regarding slavery" (p. 137).

In the run-up to Andrew Jackson's 1828 presidential bid, Van Buren constructed a new political party, the Democracy, upon this anti-emancipationist foundation. The New York politician seemed to lay bare his vision for the Democratic Party in a well-known 1827 letter to Richmond Enquirer editor Thomas Ritchie. Calling for a revival of the old political combination of "planters of the South and the plain Republicans of the North," Van Buren underscored the fact that "party attachment in former times furnished a complete antidote for sectional prejudices" (p. 214). This letter, to Forbes, highlights Van Buren's intentions: party sentiments must be revived to prevent future friction over slavery. Many historians of Jacksonian America, from Robert Remini to Sean Wilentz, have dismissed both the Ritchie letter and the role of slavery in the formation of the central Democratic-Party coalition as relatively insignificant. Forbes, however, makes a largely convincing argument that such defenders of the Democracy appear to protest too much. As he writes, "One is at a loss to know just what contemporary politicians would have had to write in order to convince Remini and others of his school that slavery represented a central issue, if not the central issue, of national politics at this time" (p. 215).

With Van Buren's help, Jackson won the election of 1828. But his victory alone did not put the slavery issue to rest. During Jackson's presidency, slavery came up again and again. From David Walker's Appeal to the rise of immediate abolitionism, from Nat Turner's insurrection to the Virginia slavery debates of 1831-32, slavery seemed everywhere in the late 1820s and early 1830s. And, of course, at the root of the Nullification Crisis lay not simply objections to the tariff and concerns about states' rights, but also fears about the future of slavery. At this critical juncture, however, another compromise was reached. Although political rivals, Andrew Jackson and Daniel Webster "laid the groundwork for a deep structure of cooperation between Jacksonians and anti-Jacksonians" (p. 265). Jackson's willingness to use force to defend the Union in the Nullification Crisis helped convince northern Unionists that "protecting slavery did not mean endangering the Union" (p. 261). In a similar fashion, Daniel Webster's fixed interpretation of the Union helped allay the worst fears of anti-abolitionists. In short, they made possible the vigorously partisan, yet stable Second Party System, by effectively cordoning off debates about slavery-either in favor or against—as un-American. Thus, although the 
ensuing decade witnessed a surge in abolitionist agitation and emancipation in the West Indies, on the one hand, and the development of more unapologetic defenses of slavery, on the other, American politicians were able to steer clear of the rock of slavery.

Yet the problem of slavery would not go away. It re-emerged in political debates on a number of issues in the 1830s and 1840s, including the admission of Michigan, the annexation of Texas, and the Mexican War and Wilmot Proviso. It even forced a return to-and rejection of-the compromise forged in the debates over Missouri. When Stephen Douglas proposed that Kansas and Nebraska be organized according to popular sovereignty, he tore open the old wound. Many of the speeches and pamphlets first produced in 1819 and 1820 were republished, and politicians, proslavery and antislavery alike, reprised their earlier roles. Things had come full circle. The Missouri Compromise had laid the foundation for the Second Party System, whereas its destruction, in the Kansas-Nebraska Act, brought that system to an end, thereby paving the way for four years of war and the end of slavery.

The Missouri Compromise and Its Aftermath is at once an impressive and frustrating book. Forbes demonstrates a clear mastery of the myriad theories, plans, and developments of the 1820s and early 1830s. His narrative winds its way through the tangled web of antebellum New York state politics and effectively surveys the wide variety of arguments marshaled by proslavery and antislavery thinkers, among many other topics. At times, Forbes's book approaches a synthesis of the period. Yet this coverage is not without its shortcomings. For one, Forbes's narrative too often loses sight of its major themes. The Missouri Compromise, for example, fades from view about a third of the way through the book. Thus, when Forbes returns to the compromise via the Kansas-Nebraska Act in his epilogue, he feels the need to add the rather awkward qualifier for a book devoted to the Missouri Compromise, "It is worth reviewing the career of the Compromise in the thirty years since we left it" (p. 275).

If the Missouri Compromise proper is absent for much of the narrative, discussions of slavery are not. Yet this fact raises a more significant problem. Forbes convincingly demonstrates that fears about reopening the dangerous debates of the Missouri crisis were often on the minds of 1820 s politicians, even if they did not say so explicitly. In his zeal to make this case, however, he occasionally goes too far. Just about every political position taken in the 1820 s and 1830s, he suggests, reflected underlying concerns about the slavery question. So, "the most important reason for the creation of the Second Party System" was southern fears about the future of slavery, while the opposition to Andrew Jackson's Indian removal bill "represented, at least in part, the sublimation of the slavery issue into less politically and constitutionally explosive channels" (pp. 8, 231). One wonders whether a cigar could ever be a cigar in 
the 1820s and 1830s. Even when Forbes admits that Jacksonian politicians cared about issues besides slavery, he cannot resist tying in the slavery question. Hence, Forbes concludes that without the mutual decision to take slavery off the table, the fierce debates about tariffs, internal improvements, and, most of all, the Second Bank of the United States would not have been possible.

Despite these shortcomings, The Missouri Compromise and Its Aftermath is a fine piece of scholarship. It should stand as the definitive work on the Missouri Compromise for quite a while and will likely spur additional research on the relationship between slavery and the rise of the Second Party System. Indeed, Forbes's most important contribution is to remind us that the story of American democracy cannot be told apart from the story of America slavery.

Ethan J. Kytle, Department of History, California State University, Fresno, is the author of "From Body Reform to Reforming the Body Politic: Transcendentalism and the Militant Antislavery Career of Thomas Wentworth Higginson," American Nineteenth Century History 8: 3 (September 2007): 325-50, and is completing a book on romantic liberals and the antislavery movement in the 1850 s and 1860s.

1. Alexis de Tocqueville, Democracy in America (1990), 1: 331.

2. See Richard S. Newman, The Transformation of American Abolitionism: Fighting Slavery in the Early Republic (2002); Adam Rothman, Slave Country: American Expansion and the Origins of the Deep South (2005); Steven Deyle, Carry Me Back: The Domestic Slavery Trade in American Life (2005); Eric Burin, Slavery and the Peculiar Solution: A History of the American Colonization Society (2005); Matthew Mason, Slavery and Politics in the Early American Republic (2006); Timothy P. McCarthy and John Stauffer, eds., Prophets of Protest: Reconsidering the History of American Abolitionism (2006); and John C. Hammond, Slavery, Freedom, and the Expansion in the Early American West (2007). 